\title{
Teologie a sociální práce - oddělené světy, slepé místo nebo interdisciplinární obohacení? Úvahy o významu teologie pro koncepce sociální práce Beate Hofmann
}

\begin{abstract}
Abstrakt
Článek vychází z německého kontextu a reflektuje možné role a funkce teologie pro teorie a metody sociální práce a praxi sociálních zařízení. Po úvodních poznámkách k vědecko-teoretickému zařazení teologie je diskutována role teologie při analýze a objasňování obrazů člověka, které jsou základem sociální práce, a prezentována na dvou příkladech pojetí identity a fragmentárnosti; následně je pozornost věnována reflexi hodnot, norem v dilematech sociální práce, objasnění potenciálu smyslu a zvládání kontingence, reflexi rituálů a zdrojů a vnímání institucionální role církve pro občanskou angažovanost či sociálně prostorové přístupy, aby byl ukázán význam teologických dimenzí pro teorii a praxi sociální práce.
\end{abstract}

Klíčová slova: teologie, sociální práce, teologická antropologie, obraz člověka

\section{Vědecko-teoretické úvahy a vnímání kontextu}

Sociální práce či sociální práce jako věda - přesná definice se zdá být velmi sporná i v rámci oboru samotného $^{1}$ - se v Německu rozvinula v průběhu emancipace sociálních věd z područí teologie. Během osvícenství a Velké francouzské revoluce byla prolomena představa, že život a také chudoba jsou Bohem předem určené či dokonce chtěné. Tím byla umožněna analýza sociálních problémů jako problémů, za které jsou zodpovědní lidé. Avšak s teoretickým a dějinným odmítnutím teologického vnímání světa a člověka, ke kterému muselo nutně dojít, byly překryty i důležité prvky duchovně dějinných tradic sociální práce. Ptáme-li se nyní na funkci teologie pro sociální práci, nejde již o „poručníkováni““ ve vnímání světa a člověka či v analýze světa každodenního života, ale o perspektivu, dílčí aspekt, vědu se vztahem k ostatním vědám popisujícím vnímání světa a člověka. Ignorovat teologii tak, jak se to nyní děje v německé sociální práci coby vědě, znamená - to je má teze - odříznout důležité kořeny sociální práce a ignorovat ústřední dimenze lidského života. Není to ku prospěchu člověka a není to správné. Odpor proti teologii je často spojován s obrazy teologie jako ideologické, nevědecké, do sebe uzavřené teorie a církve

1 Profesionální praxe řešení sociálních věcí či sociálních problémů klientů, srov. Bringfriede SCHEU - Otger AUTRATA, Theorie Sozialer Arbeit. Gestaltung des Sozialen als Grundlage, Wiesbaden: Verlag für Sozialwissenschaften, 2011. 
jako autoritářské, středověké instituce. ${ }^{2}$ Takové obrazy přehlížejí kritickou sebereflexi moderní vědecké teologie stejně jako postavení teologie a církve v podpoře těch, kteří celosvětově vystupují za svobodu, mír a zachování stvoření.

V Německu se o významu teologie pro sociální práci v současné době diskutuje především pod heslem „náboženská citlivost“. Ústřední teze zastánců tohoto stanoviska zní v souhrnu takto:

Tam, kde je náboženství v každodenním životě, v lidské životní skutečnosti centrální veličinou klientů a klientek, tam $\mathrm{k}$ němu musí být přihlédnuto a musí být zahrnuto do řešení sociálních problémů. Nábožensky slepá sociální práce či sociální práce, která není schopna mluvit náboženským jazykem, např. neosloví islamisticky či salafisticky ovlivněné mladé lidi. Jejich obraz světa mohou sociální pracovníci narušit jen tehdy, jsou-li sami schopni mluvit náboženským jazykem a mohou-li přesvědčivě hájit a žít jiný pohled na svět. K náboženské citlivosti patř́i i vnímání významu náboženských organizací pro biografii a společenský život klientů a klientek. Náboženství, vnímání náboženských potřeb, zainteresovanost na náboženských institucích jako základní dimenze lidského života hrají v ošetřovatelství, ${ }^{3}$ ale i v sociálně vědních analýzách světa každodenního života přinejmenším $\mathrm{v}$ anglosaském prostředí důležitou roli. ${ }^{4}$ Ignorovat nebo zlehčovat je jako irelevantní znamená přehlížet úlohu, kterou náboženství jako zdroj hraje v životě mnoha lidí - i ve stále více sekulárních společnostech. V následujícím textu bude $\mathrm{v}$ pěti př́ikladech pojednáno o roli teologie pro koncepce sociální práce i v podmínkách vysoké sekularity.

\section{Teologická reflexe obrazů člověka a světa}

V návaznosti na Martina Lechnera ${ }^{5}$ S Silvii Staub-Bernasconi lze v hrubých rysech načrtnout tři typy teorií sociální práce:

a) Zaměření na „člověka bez společnosti“: člověk je viděn jako autonomní, soběstačný a sebeurčující; pozornost sociální práce je odpovídajícím způsobem zaměřena na práva a nároky, seberealizaci a svobodu.

b) Dominance společenské perspektivy: pozornost teorií sociální práce je zaměřena na společenskou integraci, disciplinarizaci a stabilizaci; sociální práce je chápána jako normalizující práce.

c) Procesní a systémové potřeby, které popisují „člověka ve společnosti“a vnímají jeho potřeby; sociální práce má $\mathrm{v}$ tomto kontextu odpovídat individuálním potřebám a sociálním požadavkům.

Již v těchto málo heslech se objevují rozdílné obrazy člověka a společnosti a z nich odvozené velmi rozdílné funkce sociální práce. Co zde přináši teologická perspektiva?

Teologická analýza podporuje umění rozlišovat, např. v evangelicko-luterském pojetí člověka jako iustus et peccator (spravedlivý a hř́řník) a v jeho vztazích coram deo a coram hominibus. Tím jsou odkrývány implicitní normativní formulace týkající se podstaty člověka a poskytující

2 Martin LECHNER, Theologie in der Sozialen Arbeit (Benediktbeurer Studien 8), München: Don Bosco Medien, 2000, s. 156. Teologie se setkává s větší skepsí než filosofie, musí tím více dokazovat svou užitečnost.

3 Srov. model péče Monika KROHWINKEL, Pflegemodell, (on-line), dostupné na: https://de.wikipedia.org/wiki/Modell_der_fördernden_ Prozesspflege, citováno dne 8. 1. 2018.

4 Např v Capability-Approach M. Nussbauma, srov. Matthias NAUERTH - Kathrin HAHN - Michael TÜLLMANN - Sylke KÖSTERKE, Religionssensibilität in der Sozialen Arbeit, Stuttgart: Kohlhammer, 2017, s. 20.

5 LECHNER, Theologie in der Sozialen Arbeit, s. 164n; Silvia STAUB-BERNASCONI, Systemtheorie, soziale Probleme und Soziale Arbeit: lokal, national, international oder: vom Ende der Bescheidenheit, Bern, Stuttgart, Wien: Haupt, 1995, s. 120-133. 
odůvodnění k tématům, jako je např. hodnota života, ale i cíl lidského rozvoje (např. seberealizace). Reflexe těchto otázek patří k úkolům epistemologického a ontologického fundamentu teorií sociální práce. Vnímání teologických perspektiv přitom může přispět $\mathrm{k}$ intelektuálnímu tř́bení a diferenciaci těchto základů. Tato odvážná teze bude objasněna na dvou př́kladech.

\subsection{Teologická kritika teorií rozvoje identity}

Pojem identity hraje ústřední roli v řadě sociálně-pedagogických konceptů. Podpora rozvoje identity, zpracování poruch identity, to jsou témata v poradenské práci, v různých oblastech výchovy, ale i v krizové intervenci. ${ }^{6}$ Často je přitom používán koncept identity psychologa Erika Eriksona. ${ }^{7}$ Jeho koncept stupňů vývoje identity s ideálem kompletní, celostní identity a zralé osobnosti stojí v pozadí mnoha konceptů poradenství a doprovázení. Teolog Henning Luther poukázal na spornost tohoto ideálu kompletní, ukončené identity. Ve svém článku „Identita a fragment" používá ústřední aspekty křestanské antropologie k popisu fragmentární povahy lidské identity. Chápe fragment na jedné straně jako zlomek minulosti, na druhé straně jako neúplný a otevřený do budoucnosti. Vývoj a změna, tím i transcendence sebe sama jakožto konstitutivní znak identity, jsou podle Luthera možné jen při chápání člověka jako fragmentu. Plná identita podle něj implikuje zřeknutí se smutku, naděje a lásky.

Lutherovo chápání „identity jako fragmentu“ bere vážně jak křestanskou nauku o hř́chu, v níž je právě touha po dokonalosti, přání „chtít být jako Bůh“ chápáno jako projev hříchu. Být člověkem naopak znamená vyrovnat se s fragmentární povahou lidského bytí. Koncept chápe Krista jako pravzor fragmentární identity na křriži, ale také jako toho, kdo překonal fragmentárnost svým zmrtvýchvstáním. Ospravedlnění popisuje H. Luther jako život coby fragment, který je odkázaný na dovršení, kterého sám nemůže dosáhnout.

Tento koncept je ve velké míře nosný pro lidi, kteří musí zvládat zkušenosti krizí a zlomů, kteří jsou vytrženi ze životních plánů útěkem, migrací či elementární životní krizí, ale i společenskými zvraty. Osvobozuje je ze snah o sebeoptimalizaci, skrze něž mohou lidé dostat sami sebe do silného stresu, a které vedou $\mathrm{k}$ tomu, že jsou krize interpretovány jako osobní selhání. ${ }^{9}$

Př́stup Henninga Luthera je př́íkladem toho, jak mohou teologické kategorie relativizovat určování norem a ideální obrazy a mohou odhalit jejich vliv na omezování svobody a rozvoje. Není nutné být s Lutherovými kategoriemi zajedno, ale je třeba kriticky se vypořádat s jím identifikovanými důsledky perfekcionismu a sebeoptimalizace. $V$ tom je nápomocna jeho teologicky určená perspektiva.

\subsection{Teologická antropologie uvažovaná v napětí mezi protichůdnými póly}

Druhý příklad významu teologických obrazů člověka: obrazy člověka v sociální práci kolísají, jak již bylo úvodem zmíněno, mezi zaměřením na deficity a omezení na straně jedné a důrazem na autonomii, seberealizaci a sebeurčení na straně druhé. I perspektivy křestanské antropologie jsou na jedné straně poznamenány zásadní skepsí („,každý výtvor lidského srdce je od mládí zlý, Gn 8,21), ale také úsilím o povzbuzení lidí k vedení samostatného života a k životu podle Božích

\footnotetext{
Benjamin JÖRISSEN - Jörg ZIRFAS (Hg.), Schlüsselwerke der Identitätsforschung, Wiesbaden: Verlag für Sozialwissenschaften, 2010. Erik H. ERIKSON, Identität und Lebenszyklus, Frankfurt: Suhrkamp, 1966.

Henning LUTHER, Religion und Alltag. Bausteine zu einer praktischen Theologie des Subjekts, Stuttgart: Radius, 1992, s. 160-183.

9 Srov. Michael NÜCHTERN, Spiritualität auf dem Markt, in: Spirituelle Aufbrüche. Perspektiven evangelischer Glaubenspraxis, FS M. Seitz, hg. von Michael Herbst u. a., Göttingen: Vandenhoek \& Ruprecht, 2003, s. 9-18.
} 
přikázání („empowerment“, „Jdi a jednej také tak“, L 10,37). Obojí má - subjektivně nahlíženo na sebevědomí lidí, kteří se setkají se sociální prací jako klienti, jen malý dopad. Další úvahy zde nabízí katolická teoložka Marianny Heimbach-Steins, ${ }^{10}$ která shrnula křestanskou antropologii do pěti velmi rozdílných napětových pólů:

- autonomie

- individualita

- schopnost vztahu

- svoboda

- překročení sebe sama, distancování se od sebe sama $\leftrightarrow$ vděčnost coby stvořená bytost (za sebe a svůj život vděčit druhým)

$\leftrightarrow$ společenskost, sociální vyloučení

$\leftrightarrow$ potřeba vztahu

$\leftrightarrow$ omylnost, schopnost rozpoznat vinu

smrtelnost (zkušenost kontingence)

Lidský život je zde popisován jako pohyb v napětí mezi opačnými póly. Udržet toto napětí a nezdůrazňovat pouze jednu stranu a druhou přehlížet, to je výzva při posuzování lidských schopností a hranic. Mnoho obrazů o sobě samých, ale i reklam idealizuje jednu stranu a tabuizuje druhou: ve sportu, v povolání, ve vztazích jde o autonomii, o svobodu, o překračování hranic, o to překonat sebe sama. To je pozitivně oceňováno, ale zároveň je potlačována konfrontace s nepřekonatelnými hranicemi, jako je napřr. smrt. V sociální práci však máme většinou co do činění s lidmi tehdy, jsou-li konfrontováni s druhou stranou těchto pólů, když se musí vypořádat s vinou, potřebou vztahu, závislostí a kontingencí. Křestanský obraz člověka, který vidí člověka v tomto napětí, může vnímat potenciál i omezení lidského života a tím načrtnout realistický obraz člověka.

Takový př́stup proto může přispět $\mathrm{k}$ tomu, aby si teorie sociální práce nejprve vůbec uvědomily, že existují takovéto obrazy člověka a světa, aby je reflektovaly a aby identifikovaly a zpracovaly slepá místa v pohledu na člověka.

Teologické vnímání skutečnosti zde může mít funkci kritiky ideologie, nebot’ i když se to může zdát zarážející, je sama teologie mnohými považována za formu ideologie. Jak významným korelativem mohl a musel být křestanský pohled na člověka ve střetnutí s ideologiemi a jaké strašlivé důsledky může mít absence takového korelativu, to Charita a Diakonie v Německu zažily citelným způsobem. Nacistická politika eutanazie, která byla následně statečným odporem jednotlivých křestanů alespoň utlumena a omezena, mohla rozvinout svůj člověkem pohrdající účinek mezi lékaři a pracovníky v zařízeních pro osoby se zdravotním postižením proto, že tito pracovníci byli náchylní k rasistickým a eugenickým myšlenkám a stali se tak pomahači rasistické sociální a populační politiky. Nepostavili se na odpor nacistickému znehodnocení života lidí s postižením. Teprve zpracování této historie i vyrovnání se s přehmaty a se zneužíváním v křestananských zařízeních během nacistické diktatury zostřilo v Německu citlivost pro otázky obrazu člověka a hodnoty lidského života. ${ }^{11}$ To samé platí pro zpracování stop materialistického, na převýchovu a nápravu zaměřeného obrazu člověka $\mathrm{v}$ zařízeních NDR. ${ }^{12}$

Teologie zde podporuje etickou reflexi profesního jednání a společenských otázek týkajících se hodnot v konfrontaci s židovsko-křestanským obrazem člověka a biblickou tradicí. To se může dít

10 Srov. Marianne HEIMBACH-STEINS, Menschenbild und Menschenrecht auf Bildung. Bausteine für eine Sozialethik der Bildung, in: tamtéž; Gerhard KRUIP (Hg.), Bildung und Bildungsgerechtigkeit, Bielefeld: Bertelsmann, 2003, s. 23-43.

11 Např. Anneliese HOCHMUTH, Spurensuche: Eugenik, Sterilisation, Patientenmorde und die v. Bodelschwinghschen Anstalten, in: Matthias BENAD (in Verbindung mit Wolf Kätzner und Eberhard Warns), Bielefeld: Bethel, 1997 und exempl. https://www. diakonieneuendettelsau.de/ueber-uns/geschichte/, citováno dne 8. 1. 2018.

12 Srov. Christian SACHSE, Der letzte Schliff. Jugendhilfe der DDR im Dienst der Disziplinierung von Kindern und Jugendlichen (1945-1989), Schwerin: Landesbeauftragte f. Mecklenburg-Vorpommern f. d. Unterlagen d. Staatssicherheitsdienstes d. ehemaligen DDR, 2011. 
pouze $\mathrm{v}$ interdisciplinárním dialogu se sociální prací, ošetřovatelstvím, medicínou a podnikovou ekonomikou, aby byl společně vytvořen obraz člověka, který je charakterizován respektováním lidské důstojnosti jakožto základním postojem. Na této bázi pak mohou pracovníci posoudit odpovídající ošetřovatelské, poradenské a pečovatelské přístupy a uzpůsobit svůj všední pracovní den. Teologie zde nabízí - v dialogu s ostatními - fundament, bázi.

Tím se dostáváme $\mathrm{k}$ druhému styčnému místu, otázce hodnot a norem.

\section{Teologie jako reflexe normativních předpokladi̊ a etických dilemat}

Silvia Staub-Bernasconi poukázala v roce 1994 na nebezpečí spočívající v tom, že zaměřením se na teorie jednání $\mathrm{v}$ teoriích sociální práce bude otázkám hodnot věnováno jen málo pozornosti. ${ }^{13}$ Požadovala obsáhlou nauku o hodnotách a etice v rámci vzdělávání v sociální práci. To mělo sloužit ke zdůvodnění hodnot, $\mathrm{k}$ pomoci v hodnotových konfliktech a ke kritické diskusi při stanovování funkcí, problémů a cílů i důsledků jednání v sociální práci. Na př́íladu teorí́ identity a obrazů člověka již bylo ukázáno, jaký význam může mít reflexe normativních základů teorií a koncepcí sociální práce. Právě otázky týkající se hodnoty života se projevují v práci v zařízeních pro lidi s postižením či v poradenských střediscích pro konflikty souvisejícími s těhotenstvím. Ovlivňují postoj pracovníků k postiženým či umírajícím lidem.

Vedle základních otázek poukázala Staub-Bernasconi na dilemata a hodnotové konflikty, které patří ke všednímu dni sociální práce, např. napětí mezi sebeurčením a sebepoškozením, $\mathrm{s}$ nimiž jsou pracovníci v práci se závislými či při asistování lidem s postižením často konfrontováni. Toto dilema musí být reflektováno a zpracováno, což vyžaduje osvojení si etické reflexe.

Jeden př́klad: otázka zákoníka „A kdo je můj bližní?“ z L 10, znamená převedeno do dnešní doby např. „Komu a jak pomohu vzhledem $\mathrm{k}$ omezeným zdrojům a velké potřebě pomoci a celosvětové nouzi?"“ Tuto otázku rozhoduje sociální pracovník několikrát denně. Činí tak podle kritérií ze sociálního práva, mnohdy patrně po diskusích ve svém týmu, mnohdy i intuitivně či spontánně. Musí se přitom zabývat zkušenostmi závislosti, moci a bezmoci, osamělosti či blízkosti a distance. Aby sociální pracovníci dostáli své odpovědnosti, musí si být vědomi toho, že jejich jednání nemůže být hodnotově neutrální či dokonce bez hodnot a že vyžaduje pečlivé zvažování mezi různými dobry. Tam, kde jsou omezené zdroje pomoci, ale velká nouze, vyvstávají otázky po spravedlnosti a odpovědnosti v zacházení se zdroji. Schopnost kritické reflexe vlastního jednání vzhledem k normativním předpokladům je centrální kompetencí s ohledem na nedostatek zdrojů a konflikt cílů.

Přirozeně zde i filosofická etika nabízí důležité př́ílady a způsoby myšlení, např. aby bylo možné argumentativně uplatnit a odůvodnit radikálnost odmítnutí chovat se $\mathrm{k}$ lidství jako k prostředku a nikoli jako $k$ účelu a hájení lidství jako účelu o sobě samotném v etice Immanuela Kanta. Právě vzhledem $\mathrm{k}$ dominanci utilitaristických teorií v současné filosofii je obohacující ukázat prostřednictvím teologicky odůvodněné etické argumentace rozmanitost etického uvažování a možností odůvodnění, a podporovat tak schopnost nejen společnosti, ale i jednotlivých profesionálů vytvářet si úsudek. Kromě toho nabízí zabývání se etikou možnost osvojení si způsobů reflektovaného vytváření úsudku a tř́bení citlivosti pro etickou dimenzi sociální práce.

I zde jde o předpoklady sociální práce jako vědy, která musí objasnit vlastní normativní formulace, musí umět zpracovat přednormativní impulzy jako empatii a umět rozumět vlastnímu jednání, svým cílům, ale i omezením, při nichž k tomuto jednání dochází, a umět je zhodnotit.

13 LECHNER, Theologie der Sozialen Arbeit, s. 172. 


\section{O zacházení s horizonty smyslu a kontingencí}

V sekulární zemi snad ochabuje význam studia náboženství, avšak vyrovnávání se s konstrukcemi smyslu a jejich významem pro život klientů i profesionálů zůstává. Ukazují to výzkumy sociologie náboženství napr. na východě Německa. ${ }^{14}$ Teologie v tomto kontextu nabízí bohatou konfrontaci s perspektivami konstrukce smyslu; nabízí reflexi řečových vzorů, obrazů a tím vzory vyrovnání se $\mathrm{s}$ kontingencí. Podporuje prìtom úkol, který formuloval Hans Thiersch, ${ }^{15}$ jeden $\mathrm{z}$ předních odborníků v sociální práci v Německu, totiž zapojit kontingence do hry a začlenit je do řeči tak, aby s nimi mohl člověk žít.

Existují oblasti sociální práce, v nichž je nemožné vyhnout se takovýmto otázkám po smyslu; jejich zvládnutí je jádrem práce. To platí zejména na hranici života; s takovými otázkami se však lze setkat i v práci se závislými, v poradenství či při pomoci v rozvoji. „Proč se mi to děje?“, „Jak to vydržím?"“, „V čem je smysl mého života?“, to jsou nejčastější podoby takových otázek. Zatímco $\mathrm{v}$ ošetř̌ovatelství již patř́ zohlednění takových otázek ke standardu a zohlednění náboženských potřeb patří k základním potřebám, na které je třeba brát zřetel, jejich zakotvení v sociální práci se zdá být mnohem obtížnější. ${ }^{16}$ Především studie $z$ anglosaského prostředí vyzdvihují význam náboženských zdrojů ve vypořádávání se s krizemi smyslu jak pro klienty, tak i pro pomáhající. Srovnatelné německé studie jsou však dosud přejímány spíše váhavě. ${ }^{17}$ Alespoň v Německu je ve světě teorií sociální práce patrný „strach z cizího“ ve vztahu k teologicky ovlivněnému pojetí hermeneutiky světa každodenního života. ${ }^{18}$

Je-li „práce se smyslem“ akceptována, patří k úkolům sociální práce v ní lidi podporovat. Takováto práce týkající se výkladu, interpretace smyslu vyžaduje vlastní kompetence. Obrazy a řečové vzory sloužící ke zvládnutí této interpretační práce pocházejí z různých myšlenkových tradic a náboženství, jsou zakotvené v kulturní paměti a jsou dnes rozmanitě kombinovány, jak ukazuje sociologie náboženství. Porozumění těmto řečovým vzorům, jejich, možná i kritické, zkoumání a zasazení do nového kontextu, vyžaduje znalost vzorců, jejich intelektuální proniknutí a zpracování.

Ten, kdo chce lidi podporovat $v$ interpretování smyslu, musí sám ovládat tuto interpretační práci a musí umět reflektovat vlastní výkladové vzorce. Mưže se tak dít př̀i supervizi nebo při kolegiální poradě, pomáhat zde mohou i spirituální společenství a místa. V Německu se právě formuje sít pro komunikaci a spiritualitu týkající se existenciálních otázek, která v sociálních organizacích podporuje pracovníky $\mathrm{v}$ tom, aby rozvíjeli formy a podoby komunikace o existenciálních otázkách a nalézali místa pro reflektování vlastních otázek. ${ }^{19} \mathrm{~V}$ podpoře takovýchto snah spočívá další funkce křestanské teologie v sociální práci. Přirozeně je právě v této oblasti důležité být si jasně vědom hranic vlastního konání a vlastních možností. Ne na každou otázku existuje odpověd, a právě v této oblasti existují situace, kdy mohou sociální pracovníci a klienti společně vyjádřit jen svou bezradnost. Víra zde může být důležitým zdrojem při zvládání aporií a může chránit před přehnanými očekáváními co se týče pomoci a uzdravení.

14 Srov. Monika WOHLRAB-SAHR - Friedericke BENTHAUS-APEL, Weltsichten, in: Kirche in der Vielfalt der Lebensbezüge, in: Wolfgang HUBER - Johannes FRIEDRICH - Peter STEINACKER (Hg.) (4. EKD-Erhebung über Kirchenmitgliedschaft), Gütersloh: Gütersloher Verlagshaus, 2006, s. 279-330.

15 Srov. Hans THIERSCH, Lebenswelt und Moral. Beiträge zur moralischen Orientierung sozialer Arbeit, Weinheim, München: Juventa, 1993, s.71n. Dále srov. LECHNER, Theologie der Sozialen Arbeit, s.189.

16 Srov. zmíněnou diskusi o náboženské citlivosti v sociální práci, NAUERTH - HAHN -TÜLLMANN - KÖSTERKE, Religionssensibilität in der Sozialen Arbeit.

17 Srov. Heike LUBATSCH, Führung macht den Unterschied. Arbeitsbedingungen diakonischer Pflege im Krankenhaus, (viz konkrétně 5), Berlin u. a.: Lit-Verlag 2012; dále srov. Tim HAGEMANN, Arbeit, Gesundheit, Spiritualität \& Religiosität. Forschungsbericht (o. J., ca. 2013) (on-line), dostupné na: http://www.ekd.de/si/download/Bericht.pdf, citováno dne 14. 1. 2014.

18 Srov. k analýze LECHNER, Theologie der Sozialen Arbeit, s. 183n.

19 Srov. viz @ NEKS (on-line), dostupné na: www.netzwerk-eks.de, citováno dne 8. 1. 2018. 


\section{Spirituální dimenze}

V právě řečeném jsou zároveň obsaženy otázky týkající se resilience a salutogeneze. Otázky typu „Jak to vydržím?"“, „Jak zůstanu zdravý?" se v sociální práci vždy stávají ústř̌edními otázkami nejen ve vztahu ke klientům, ale i k pracovníkům. Z výzkumu syndromu vyhoření zde vyvstávají zajímavé možnosti navázání na znalosti křestanství v oblasti spirituality. Jedná se zde o ritualizaci v běžném životě, o kulturu odpočinku a význam přestávek. Znalost významu takovýchto zdánlivých maličkostí je na řadě míst obětována ekonomické racionalizaci, aniž by byla brána v úvahu z toho vznikající ekonomická škoda. Výzkumy v oblasti podnikové kultury jsou zaměřené na to, přesvědčit ekonomy a specialisty v oboru sociálních věd o významu rituálů, přestávek, vědomého utváření důležitých životních prahů jak v životě uživatelů, pracovníků či celých organizací. ${ }^{20}$ Teologie zde přichází v úvahu jako vykladač a tvůrce životních prahư; přináší perspektivu, která se na mnohých místech stala cizí, přináší novou citlivost pro dobu a prostředí, pro rytmus a jeho účinky na zdraví a kompetenci ve zvládání života. Nejedná se zde o ezoteriku, ale o hlavní zdroje vědění týkající se zvládání elementárních zkušeností jako je stres, smutek, bezmoc, osamělost a tomu odpovídající účast, vytváření společenství, sociální zvládání diference a vnímání všedního dne. Citlivost pro takové otázky a príležitosti patř́ fundamentálně k teoriím a metodám sociální práce; při vytváření konkrétních forem se lze, avšak nemusí, učit od praktické teologie.

Tím se dostáváme k poslední dimenzi popisu významu teologie pro teorie a koncepce sociální práce.

\section{Institucionální dimenze a otázka občanské společnosti a sociálního prostoru}

V této dimenzi jde o otázku týkající se institucí společenské soudržnosti a role církve a křestanských organizací pro společnost. Může se to jevit jako velmi německá perspektiva. Zde hrají církve a křestanské organizace důležitou roli při hledání toho, co umožňuje společnosti fungovat, co pomáhá zachovávat rovnováhu mocenských instancí ve státě a pomáhá př̀i zvládání velkých společenských výzev. To však platí i pro mnoho zemí Afriky a Latinské Ameriky, dokonce i pro Č́nu. Aby bylo možné vnímat význam křestanských organizací pro občanskou společnost a rozumět fungování těchto organizací, je zapotřebí teologické kompetence a systémové kompetence vzhledem k církevnímu systému.

V Německu vzbudila role církví a organizací občanské společnosti při zvládání přistěhovalecké vlny 1 milionu uprchlíků v roce 2015 diskusi o významu dobrovolnictví a občanské společnosti. Komercionalizací a ekonomizací zdraví a sociálních věcí získává angažovanost občanské společnosti nový význam. Vymyká se logice finanční odměny a logice sociálního státu a začíná tam, kde lidé vidí sociální potřebu a kde chtějí a mohou angažovaně pomáhat a sami se k pomoci zorganizovat - aniž by nejprve museli vysvětlovat otázku refinancování sociálního jednání. Př́íkladem je práce potravinových bank, zakládání hospicủ či práce v zařízeních pro uprchlíky. Mnohé formy pomoci, jako např. práce pro hospice, jsou na mnoha místech již trvale financovány a staly se součástí systému zdravotní péče. Jiné oblasti si zachovávají svou komplementární funkci.

Sociologické analýzy ukazují, že mimořádný potenciál církví a jejich diakonické práce spočívá na jedné straně v podpoře interpersonální a institucionální důvěry. ${ }^{21}$ Církevní a diakonické orga-

20 Srov. Beate HOFMANN, Diakonische Unternehmenskultur. Handbuch für Führungskräfte, Stuttgart: Kohlhammer, 2010, (on-line) dostupné na: www.diakoniewissenschaft-idm.de/unternehmenskultur, citováno dne 8. 1. 2018.

21 Gert PICKEL, Religiöses Sozialkapital. Evangelische Kirche als Motor gesellschaftlichen Engagements, in: Evangelische Kirche in Deutschland (Hg.), Engagement und Indifferenz - Kirchenmitgliedschaft als soziale Praxis. V. EKD-Erhebung über Kirchenmitgliedschaft, Hannover: EKD 2014, (on-line) dostupné na: https://www.ekd.de/ekd_de/ds_doc/ekd_v_kmu2014.pdf, citováno dne 8. 1. 2018, s. $108-116$. 
nizace nabízejí „bohaté spektrum struktur př́ležitostí, které umožňují osvojení si důvěry“. ${ }^{22}$ Tato důvěra je důležitým základem pro soudržnost společnosti. U členů církví se ukazuje, že důvěra v lidi jiného náboženského vyznání je srovnatelně větší, takže je zde patrný „rozdíly překonávající a spojující sociální kapitál“. ${ }^{23}$ Tento sociální kapitál je posilován hodnotami jako láska k bližnímu a je v úzkém spojení s dobrovolnou angažovaností.

Na druhé straně nabízejí církve mnohotvárnou sít a kontakty na jiné organizace. Mnoho církevních obcí v Německu je propojeno ve své obci, se spolky a jinými náboženskými společnostmi. ${ }^{24}$ Tyto kontakty v občanské společnosti jsou „pokladem“, jehož potenciál není často vědomě vůbec vnímán. ${ }^{25}$

Sociální práce nesmí tento potenciál přehlížet, musí se naučit s ním pracovat, především s ohledem na koncepce orientace na sociální prostory nebo rozvoj sociálního bydlení. $\mathrm{K}$ tomu je zapotřebí znalost systému týkajícího se církví a křestanských organizací a schopnost spolupracovat s prŕslušnými subjekty a s dobrovolníky a nevidět v nich hlavního ideologického nepřítele.

\title{
7. Závěr
}

Aby mohla teologie plnit zde naznačené úkoly a funkce, musí splňovat určité podmínky. Musí být kontextuální a nesmí se bát reflexe a kritického osvětlování konkrétních zkušeností a souvislostí. Musí být elementární a zároveň diferencovaná. Musí hermeneuticky reflektovat vlastní předpoklady myšlení a vydržet zpochybňování nároků na pravdu. Musí umět překládat své vlastní jazykové hry do jazykového světa pedagogiky, sociálních věd nebo filosofie, a být tak schopná mluvit interdisciplinárně a být „polyfonní“. A občas musí být odvážná a zaujatá, jde-li o zpochybňování ideologických formulací nebo mocenských nároků. Právě tehdy se ukáže, zda teologie působí fundamentálně, nebo spíše jako ozdobná šlehačka, bez které se lze obejít, je navíc nezdravá a přibírá se po ní.

A rozvíjející se sociální práce jakožto věda se svými teoriemi a koncepcemi musí zvážit, zda chce a může rezignovat na fundamentální příspěvek teologie k objasnění svých normativních základů, či zda by tím nepropásla šanci na interdisciplinární obohacení ve vnímání světa každodenního života lidí i v antropologických a etických fundamentech své vědy.

Překlad: Mgr. et Mgr. Jana Maryšková

\author{
Kontakt \\ Prof. Dr. theol. Beate Hofmann \\ Kirchliche Hochschule Wuppertal/Bethel \\ Lehrstuhl für Diakoniewissenschaft und Diakoniemanagement \\ Bethelweg 8, 33617 Bielefeld \\ hofmann@diakoniewissenschaft-idm.de
}

22 Gunther SCHENDEL, Zivilgesellschaftliche Potentiale. Warum die Kirchen einen wichtigen Beitrag zur Zivilgesellschaft leisten (und wie sie selbst davon profitieren können), eNewsletter Wegweiser Bürgergesellschaft 10/2015, ze dne 03. 06. 2015.

23 Vgl. Gert PICKEL - Anja GLADKIRCH, Säkularisierung, religiöses Sozialkapital und Politik. Religiöses Sozialkapital als Faktor der Zivilgesellschaft und als kommunale Basis subjektiver Religiosität, in: Antonius LIEDHEGENER - Jacqueline WERKNER (Hg.), Religion zwischen Zivilgesellschaft und politischem System. Befunde - Positionen - Perspektiven, Wiesbaden: Verlag für Sozialwissenschaften, 2011, s. 81-109:99.

24 Přes 52 \% dobrovolníků v Diakonii se angažuje i mimo ni. Diakonie texte 04. 2012, (on-line) dostupné na: https://www.diakonie.de/ fileadmin/user_upload/Diakonie/PDFs/Diakonie-Texte_PDF/Texte-04-2012-Freiwilliges_Engagement.pdf, citováno dne 8. 1. 2018 , s. 34. Srov. SCHENDEL, Zivilgesellschaftliche Potentiale, s. 3. 